\title{
Viral encephalopathy and retinopathy (VER) in Mediter- ranean wild and farmed fish species: the experience of the Istituto Zooprofilattico Sperimentale of Sicily (Italy)
}

\author{
Giuseppa Purpari, Giusi Macaluso, Santina Di Bella*, Francesco Mira, Vincenza Cannella, Francesca Guc- \\ ciardi, Alessandra Castiglia, Patrizia Di Marco \& Annalisa Guercio
}

Istituto Zooprofilattico Sperimentale della Sicilia “A. Mirri” Via G. Marinuzzi 3, 90129 Palermo, Italy

"Corresponding author, e-mail: santinadibella78@gmail.com

\begin{abstract}
Betanodavirus infection is widespread in a broad spectrum of fish species worldwide. In Italy, it is responsible for outbreaks of Viral Encephalo-Retinopathy (VER) that causes mortality and economic losses in sea fish farming. The infection is also widespread in wildlife, where there are generally no observed clinical manifestations. In this study we report the results obtained from the decennial activity of Istituto Zooprofilattico Sperimentale of Sicily on the research of Betanodavirus infection in wild fish of Mediterranean Sea and in farmed fish. Among the fish species analyzed, Gobius niger (Linnaeus, 1758), Mullus barbatus (Linnaeus, 1758), and Trisopterus minutus capelanus (Lacepède, 1800) were found positive and these could be a reservoir in which the virus can survive for long periods of time. The Betanodavirus isolation from pelagic species such as Pagellus erythrinus (Linnaeus, 1758), Sardina pilchardus (Walbaum, 1792), Lepidopus caudatus (Euphrasen, 1788), Epinephelus marginatus (Lowe, 1834), Epinephelus aeneus (Geoffroy Saint-Hilaire, 1817) resulted interesting because these species could play a more significant epidemiological role, being able to move even at distances.
\end{abstract}

KEY WORDS Viral encephalopathy and retinopathy (VER); Betanodavirus; sea fish; farmed fish.

Received 28.11.2019; accepted 19.12.2019; published online 20.12.2019

Proceedings of the 4th International Congress on Biodiversity "Man, Natural Habitats and Euro-Mediterranean Biodiversity", November 17th-19th, 2017 - Malta

\section{INTRODUCTION}

Betanodavirus is non-enveloped, spherical and approximately $25 \mathrm{~nm}$ in diameter, RNA virus belonging to the family of Nodaviridae (Schneemann et al., 2005). The genome consists of two molecules of positive-sense ssRNA: RNA1 (3.1 kb) encodes the replicase $(110 \mathrm{kDa})$ and RNA2 $(1.4 \mathrm{~kb})$ encodes the coat protein $(42 \mathrm{kDa})$. Since 1995 the ERV has also been reported in Italy where the most affected species is European bass, Dicentrarchus labrax (Linnaeus, 1758). It is responsible for outbreaks of
Viral Encephalo-Retinopathy (VER) otherwise known as viral nervous necrosis (VNN), considered to be a serious disease of several marine fish species, characterised by significant losses associated to vacuolating lesions of the central nervous system and the retina. To date, the disease has been reported in more than 50 fish species, mainly marine with the greatest impact being in striped jack, European sea bass (Dicentrarchus labrax), groupers, and flatfishes (Munday et al., 2002; Sano et al., 2011).

VER causes mortality and economic losses in sea fish farming; the infection is also widespread 
in wildlife (Gagnè et al., 2004; Guercio et al., 2004), where there are generally no observed clinical manifestations. A few outbreaks have also been documented in freshwater farms (Bovo et al., 2011; Chi et al., 2003) suggesting that salinity is not a limiting factor and it is possible that the virus may spread to economically important freshwater species. Interspecies transmission has been demonstrated and the presence of asymptomatic carriers in wildlife is strongly suspected. The risk of horizontal transmission between wildlife and farmed fish is particularly high in fattening farming of marine fish that is generally conducted in sea cages or in brackish ponds where there is high possibility of contact with natural environment (Ciulli et al., 2007). Furthermore, the presence of Betanodaviruses was detected in bivalve molluscs. This invertebrates when reared in the same area as farmed and wild finfish could act as a reservoir of the virus. Current European regulations allow relaying activities and the sale of live bivalve molluscs, which could pose a real risk of spreading Betanodaviruses across different geographic regions (Volpe et al., 2017). Knowledge regarding the extent of disease spread is fundamental for its direct prophylaxis and control.

In this study, we reported the results obtained from the decennial activity of Istituto Zooprofilattico Sperimentale (IZS) of Sicily on the research of Betanodavirus infection in wild fish of Mediterranean Sea and in farmed fish (Ciulli et al., 2005; Ciulli et al., 2006a; Ciulli et al., 2006b; Guercio et al., 2004; Nishizawa et al.,1994; Purpari et al., 2007; Toffan et al., 2014).

\section{MATERIAL AND METHODS}

Between 2004 and 2016, a total of 1614 tests for Betanodavirus (RT-PCR and viral isolation on cell cultures) were performed on brain samples of wildcaught and farm-raised fishes along the coasts of Sicily (Italy).

\section{Viral isolation on cell cultures}

Brain samples were homogenised with 1:5-1:10 volumes of Hanks' balanced salt solution (HBSS, Sigma-Aldrich) containing antibiotics (penicillin 800 International Units $[\mathrm{IU}] / \mathrm{ml}$ and streptomycin -
$800 \mu \mathrm{g} / \mathrm{ml}$ ) to avoid bacterial contaminations. The antibiotic treatment was performed for 4 hours at $15^{\circ} \mathrm{C}$ or overnight at $4^{\circ} \mathrm{C}$.

The antibiotic treated tissue suspension at two different dilution: the primary dilution in culture medium L-15 (Sigma-Aldrich) and a 1:10 dilution thereof, were inoculated on SSN-1 cells (cell line derived from striped snakehead (Frerichs et al., 1996) and incubated at a temperature of $+25^{\circ} \mathrm{C}$. The cells were monitored by microscopy daily for 10 days in order to highlight the presence of a cytopathic effect (ECP) attributable to the presence of the virus. If no CPE occurred after the primary incubation period, subcultivation was performed on fresh cultures, using a similar cell growing area to that of the primary culture.

\section{One Step RT-PCR}

Viral RNA was extracted from brain samples and cell culture supernatants using the High Pure Isolation Kit (Roche) according the manufacturer's instructions. Total RNA was subjected to reverse transcription followed by PCR amplification performed by AccessQuickTM RT-PCR System (Promega) following the manufacturer's recommendations. A pair of primers, designated as OIEF2/ OIE-R3 (Table 1), specific for a $427 \mathrm{bp}$ fragment of the T4 region of the RNA2 gene coding for the $42 \mathrm{KDa}$ capsid protein (Nishizawa et al.,1994) was used. The thermocycling conditions were: $+54^{\circ} \mathrm{C}$ for $30 \mathrm{~min},+92^{\circ} \mathrm{C}$ for $2 \mathrm{~min}$ and 35 cycles of $30 \mathrm{~s}$ denaturation at $+94^{\circ} \mathrm{C}, 30 \mathrm{~s}$ annealing at $+55^{\circ} \mathrm{C}$ and $30 \mathrm{~s}$ elongation at $+72^{\circ} \mathrm{C}$; the reaction was terminated with a 7 min elongation at + $72^{\circ} \mathrm{C}$.

The methods used were consistent with what is described in the O.I.E. Manual (2013) and certified according to UNI EN ISO/IEC 17025:2018 quality standards.

\begin{tabular}{|c|c|}
\hline PRIMERS & SEQUENCE \\
\hline OIE-F2 & 5'-CGT GTC AGT CAT GTG TCG CT-3' \\
\hline OIE-R3 & 5'-CGA GTC AAC ACG GGT GAA GA-3' \\
\hline
\end{tabular}

Table 1. Primers used in One Step RT-PCR. 


\section{RESULTS}

Over a decade of activity, a total of 736 virus isolations on cell cultures (Table 2) and 878 RT PCR for Betanodavirus (Table 3) have been performed on brain samples of wild fish and breeding species from all over Sicily. A total of 88 samples were positive in RT-PCR and 126 by the culture method. The discrepancy in the results is due to the fact that it has not always been possible to analyze the samples with both methods; in particular, none of the 2004 samples and not all the 2005 samples were examined by the RT-PCR. SSN-1 cells inoculated with positive samples showed the presence of a cytopathic effect (ECP) attributable to the presence of the virus (Figs. 1, 2).

The "Fish, Crustaceans and Molluscs Disease Reference National Centre of the IZS Venezie" confirmed the positives. Among the species positive for Betanodavirus are commonly affected species such

\begin{tabular}{|c|c|c|c|c|}
\hline YEAR & $N^{\circ}$. TEST/YEAR & NEGATIVE & POSITIVE/FISH SPECIES & WILD/FARMED FISH \\
\hline 2004 & 5 & 3 & $\begin{array}{c}1 \text { Pagellus erythrinus } \\
1 \text { Trisopterus minutus capellanus }\end{array}$ & wild \\
\hline 2005 & 369 & 307 & $\begin{array}{c}50 \text { Gobius niger } \\
5 \text { Sardina pilchardus } \\
6 \text { Mullus barbatus } \\
1 \text { Trachiurus trachiurus }\end{array}$ & wild \\
\hline 2006 & 97 & 97 & 0 & \\
\hline 2007 & 99 & 99 & 0 & \\
\hline 2008 & 97 & 97 & 0 & \\
\hline 2009 & 11 & 3 & 8 Epinephelus marginatus & wild \\
\hline 2010 & - & - & - & \\
\hline 2011 & - & - & - & \\
\hline 2012 & - & - & - & \\
\hline 2013 & 1 & 0 & 1 Epinephelus aeneus & wild \\
\hline 2014 & 57 & 4 & $\begin{array}{l}2 \text { Epinephelus marginatus } \\
51 \text { Dicentrarchus labrax }\end{array}$ & $\begin{array}{l}\text { wild } \\
\text { farmed }\end{array}$ \\
\hline 2015 & - & - & - & - \\
\hline 2016 & - & - & - & - \\
\hline TOT & 736 & 610 & 126 & - \\
\hline
\end{tabular}

Table 2. Results of the VER isolation on SSN-1 cells from fish brains from 2004 to 2016. 


\begin{tabular}{|c|c|c|c|}
\hline \hline YEAR & N $^{\circ}$ TEST/YEAR & POSITIVE & NEGATIVE \\
\hline 2005 & 165 & 23 & 142 \\
\hline 2006 & 58 & 0 & 58 \\
\hline 2007 & 151 & 0 & 151 \\
\hline 2008 & 225 & 2 & 223 \\
\hline 2009 & 52 & 8 & 44 \\
\hline 2010 & 15 & 0 & 15 \\
\hline 2011 & 5 & 0 & 5 \\
\hline 2012 & 3 & 0 & 3 \\
\hline 2013 & 102 & 0 & 5 \\
\hline 2014 & 58 & 53 & 39 \\
\hline 2015 & 41 & 2 & 3 \\
\hline 2016 & 3 & 0 & 790 \\
\hline TOT & 878 & 88 & \\
\hline \hline
\end{tabular}

Table 3. Results obtained in RT-PCR for VER performed on fish brains from 2005 to 2016.

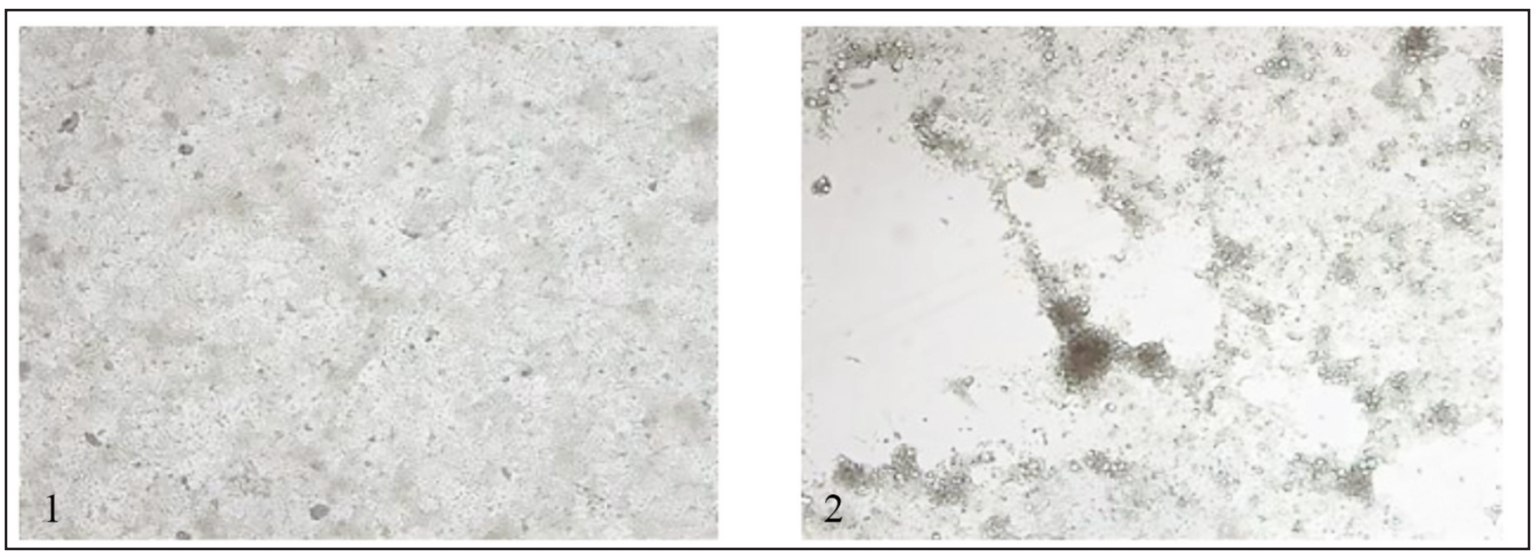

Figures 1, 2. SSN-1 monolayer (Fig. 1) andECP induced by VER on SSN-1 cells (Fig. 2).

as Dicentrarchus labrax, wild benthic species such as Gobius niger (Linnaeus, 1758), Mullus barbatus (Linnaeus, 1758) and Trisopterus minutus capelanus (Lacepède, 1800) and wild pelagic species very common in the Mediterranean Sea such as Pagellus erythrinus (Linnaeus, 1758), Sardina pilchardus (Walbaum, 1792), Lepidopus caudatus (Euphrasen, 1788), Epinephelus marginatus (Lowe, 1834), Epinephelus aeneus (Geoffroy SaintHilaire, 1817). A total of 55 strains of Betano- davirus have been also cryo-preserved in liquid nitrogen.

\section{DISCUSSION AND CONCLUSIONS}

Since 2004, IZS of Sicily in collaboration with IZS delle Venezie is concerned with the research of Betanodavirus, highlighting its widespread diffusion in breeding species and in many wild species 
of the Mediterranean Sea, in which, in most cases, the presence of virus had never been reported. Among the species that were positive, Gobius niger, Mullus barbatus and Trisopterus minutus capellanus can be reservoir in which the virus can survive for long periods of time. The isolation of Betanodavirus from pelagic species such as Pagellus erythrinus, Sardina pilchardus, Trachiurus trachiurus, Epinephelus marginatus, Epinephelus aeneus has aroused particular interest.

In fact, these species could play a more significant epidemiological role, being able to travel a large distance and these could easily be in touch with farmed fish, bringing infection from a farm to others. Such a wide spread of the pathogen, even in a natural environment, makes it necessary to investigate the existing epidemiological correlations between infection in farmed and wild species for the close contact between the two environments.

\section{REFERENCES}

Bovo G., Gustinelli A., Quaglio F., Gobbo F., Panzarin V., Fusaro A., Mutinelli F., Caffara M. \& Fioravanti M.L., 2011. Viral encephalopathy and retinopathy outbreak in freshwater fish farmed in Italy. Diseases of Aquatic Organisms, 96: 45-54. https://doi.org/ 10.3354/dao02367.

Chi S.C., Shieh J.R. \& Lin S.J. 2003. Genetic and antigenic analysis of betanodaviruses isolated from aquatic organisms in Taiwan. Diseases of Aquatic Organisms, 55: 221-228. https://doi.org/10.3354/ dao055221

Ciulli S., Natale A., Cannella V., Purpari G., Di Marco P., Ferrantelli V., Castiglione F., Scagliarini A., Guercio A., 2005. Evidenziazione dell'infezione da Betanodavirus in specie ittiche selvatiche in Sicilia. Atti del XII Convegno Nazionale S.I.P.I. (Società Italiana Patologia Ittica), 2. Cesenatico, FC 1 ottobre 2005.

Ciulli S., Galletti E., Grodzki M., Di Marco P., Dall'Orfano G., Alessi A., Purpari G., Cannella V., Castiglione F., Guercio A., Battilani M., Scagliarini A. \& Prosperi S., 2006a. Isolation and genetic characterization of betanodavirus from wild marine fish from Mediterranean Sea, Atti del VNN2006. First International Symposium on Viral Nervous Necrosis of Fish, 21. Hiroshima, Japan 28 novembre/1 dicembre 2006.

Ciulli S., Di Marco P., Natale Al., Galletti E., Battilani M., Scagliarini A., Purpari G., Cannella V., Castiglione F. \& Guercio A., 2006b. Evidenziazione e caratterizzazione di Betanodavirus in specie ittiche selvatiche nel mare di Sicilia. Ittiopatologia, 3: 101112.

Ciulli S., Galletti E., Grodzki M., Alessi A., Battilani M. \& Prosperi S., 2007. Isolation and Genetic Characterization of Betanodavirus from Wild Marine Fish from the Adriatic Sea. Veterinary Research Communications, 31 (Suppl. 1): 221-224. https://doi.org/10. 1007/s11259-007-0010-y.

Gagnè N., Johnson S.C., Cook-Verslott M., MacKinnon A.M. \& Olivier G., 2004. Molecular detection and characterization of nodavirus in several marine fish species from the northeastern Atlantic. Diseases of Aquatic Organisms, 62: 181-189. https://doi.org/10. 3354/dao062181

Guercio A., Cannella V., Ciulli S., Purpari G., Di Marco P., Ferrantelli V., Castiglione F., Galletti E. \& Scagliarini A., 2004. Diagnosis of Betanodavirus infection in wild fish species from Sicily. Abstract book 5th National Congress of the Italian Society of Virology, 64.

Manual of Diagnostic Tests for Aquatic Animals - O.I.E.Edition 2013, Part 2, Section 2.3., Chapter 2.3.12.: Viral Encephalopathy and Retinopathy.

Munday B.L., Kwang J. \& Moody N., 2002. Betanodavirus infections of teleost fish: a review. Journal of Fish Diseases, 25: 127-142. https://doi.org/10.1046/ j.1365-2761.2002.00350.x

Nishizawa T., Mori K., Nakai T., Furusawa I. \& Muroga K., 1994. Polymerase chain reaction (PCR) amplification of RNA of striped jack nervous necrosis virus (SJNNV). Diseases of Aquatic Organisms, 18: 103107.

Purpari G., Cannella V., Di Bella S., Russotto L., Alimena G., Dara S., Di Marco P. \& Guercio A., 2007. Comparazione tra varie RT-PCR e isolamento virale per la diagnosi di nodavirosi in specie ittiche selvatiche. Atti Istisan Congressi 07/C3 del II Workshop nazionale di virologia veterinaria. Diagnostica ed epidemiologia delle infezioni virali degli animali, 66. Bologna 7/8 giugno 2007.

Sano M., Nakai T. \& Fijan N., 2011. Viral diseases and agents of warmwater fish. In: Woo P.T.K \& Bruno D.W. (Eds.), Fish Diseases and Disorders, Vol. 3: Viral, Bacterial and Fungal Infections, 2nd edition. CABI, London, UK, 166-244.

Schneemann A., Ball L.A., Delsert C., Johnson J.E. \& Nishizawa T., 2005. Family Nodaviridae. In: Fauquet C.M., Mayo M.A., Maniloff J., Desselberger U. \& Ball L.A. (Eds.), Virus Taxonomy, Eighth Report of the International Committee on Taxonomy of Viruses. Elsevier Academic Press, London, UK, 865-872.

Toffan A., Fusco G., Patarnello P., Panzarin V., Pascoli F., Ceolin C., Lucifora G., Amoroso M.G., Viscardi M., Di Nocera F., Purpari G., La Cavera E., Guercio 
A. \& Marino F., 2014. Moria anomala di cernie selvatiche nel sud Tirreno: un caso di betanodavirosi. Atti del XX Convegno Nazionale S.I.P.I. (Società Italiana di Patologia Ittica). Pisa 18/19 settembre 2014.
Volpe E., Grodzki M., Panzarin V., Guercio A., Purpari G., Serratore P. \& Ciulli S., 2017. Detection and molecular characterization of betanodavirus retrived from bivalve molluscs. Journal of Fish Diseases, 41: 1-9. https://doi.org/0.1111/jfd.12759 